\title{
Ageing Migrants and the Creation of Home: Mobility and the Maintenance of Transnational Ties
}

DOI:

10.1002/psp.1994

Document Version

Accepted author manuscript

Link to publication record in Manchester Research Explorer

\section{Citation for published version (APA):}

Buffel, T. (2015). Ageing Migrants and the Creation of Home: Mobility and the Maintenance of Transnational Ties. Population, Space and Place. https://doi.org/10.1002/psp.1994

\section{Published in:}

Population, Space and Place

\section{Citing this paper}

Please note that where the full-text provided on Manchester Research Explorer is the Author Accepted Manuscript or Proof version this may differ from the final Published version. If citing, it is advised that you check and use the publisher's definitive version.

\section{General rights}

Copyright and moral rights for the publications made accessible in the Research Explorer are retained by the authors and/or other copyright owners and it is a condition of accessing publications that users recognise and abide by the legal requirements associated with these rights.

\section{Takedown policy}

If you believe that this document breaches copyright please refer to the University of Manchester's Takedown Procedures [http://man.ac.uk/04Y6Bo] or contact uml.scholarlycommunications@manchester.ac.uk providing relevant details, so we can investigate your claim.

\section{OPEN ACCESS}




\section{Ageing Migrants and the Creation of Home: Mobility and the Maintenance of Transnational Ties}

Tine Buffel ${ }^{*}$

School of Social Sciences, Sociology, Manchester Institute for Collaborative Research on Ageing, University of Manchester, Manchester, United Kingdom

\begin{abstract}
This paper combines two strands of literature that hitherto have often been kept separate in studies of ageing migrants: research in environmental gerontology on the one hand and work dealing with transnational migration on the other. In doing so, it aims to contribute to the understanding of the ways in which ageing migrants experience the notion of 'home', both as a location and a set of relationships that contribute to feelings of belonging and identity. The paper is based on 34 interviews with first-generation Turkish migrants living in inner-city districts of Brussels. The paper reviews the variety of ways in which 'home' is experienced and created, the constraints and environmental pressures which may prevent people from developing a sense of home, and the meaning of transnational ties and mobility for the experience of home. Copyright $(\subset) 2015$ John Wiley \& Sons, Ltd.
\end{abstract}

Accepted 4 September 2015

Keywords: ageing in place; environmental gerontology; home; belonging; Turkish migrants; transnationalism

\section{INTRODUCTION}

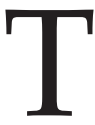

his paper combines two strands of literature that hitherto have often been kept separate in studies of ageing migrants:

*Correspondence to: Tine Buffel (PhD), School of Social Sciences, Sociology, Manchester Institute for Collaborative Research on Ageing, University of Manchester, Manchester, United Kingdom.

E-mail: tine.buffel@manchester.ac.uk research in environmental gerontology on the one hand and work dealing with transnational migration on the other. In particular, it aims to contribute to an understanding of the ways in which ageing migrants experience and give meaning to the notion of 'home', both as a location and a set of relationships that contribute to feelings of belonging and identity (Ralph \& Staeheli, 2011).

Environmental perspectives on ageing have been especially important for increasing our understanding of the interactions between older people and their physical-social environments (Wahl \& Oswald, 2010). A key argument is that the meaning of, and attachment to 'home' and 'place' are especially significant for older adults, for three reasons: first, the long period of time likely to have been spent in the same locality (Phillipson, 2007); second, the greater time spent at home following retirement (Peace et al., 2005); and, third, the significance of place in preserving a sense of identity and independence in old age (Rowles, 1986).

Environmental gerontology has raised significant issues about how neighbourhoods and residential spaces facilitate a sense of home in later life. However, the lack of theoretical innovation has also been raised as a major concern in this field. Phillipson (2007) and Wahl and Oswald (2010), for example, note limited attention to the contextual forces and macro-level changes that shape person-environment relationships in old age. Two such dimensions include the forces associated with globalisation and transnational migration, both of which offer a way of re-thinking issues about ageing and the environment. Research dealing with transnationalism provides insights into the ways in which migrants develop connections and networks that link homes in their place of origin and those to which they 
move (Gardner, 2006; Ralph \& Staeheli, 2011). Although such themes are widely discussed, they have rarely engaged with issues of age and ageing in the migration process (Torres, 2013).

This paper aims to make a contribution to our knowledge and understanding of the meaning and creation of 'home' for migrants who are 'ageing in place'. 'Ageing in place' is a term that is often used in social and environmental gerontology to refer to the idea of being able to remain at home in the community for as long as possible while ageing (Buffel et al., 2012a). Understanding the experiences of people who are ageing in a place other than their place of origin requires attention to the processes through which a sense of home is created and re-created. The next section of the paper explores linkages between the environmental gerontology literature and transnational migration studies dealing with the notion of home.

\section{Home and Place Attachment in Old Age}

Issues about home, place, and the environment have emerged as influential themes in the study of ageing. They have been especially important in the development of the sub-discipline of environmental gerontology which emerged through the work of Carp (1966) and Lawton (1982). These authors examined the reasons why some physical contexts achieved a better fit with the needs and abilities of older residents than others. The 'Press Competence model' (Lawton \& Nahemow, 1973) developed as an influential framework for understanding person-environment relationships. The assumption behind this approach is that individual behaviour is a result of congruence between the demand character of the environment (environmental press) and the capabilities of the person to deal with that demand (personal competence). This model addresses the ways in which the mismatch between personal needs and environmental options to fulfil these needs can undermine wellbeing in later life.

Through the 1980s and 1990s, new perspectives developed relating to ageing and the environment. Drawing upon a phenomenological approach, Rowles (1986) focused on the experiential dimension to home and place attachment in old age. He developed the argument that older people who have resided in the same community for a long period of time maintain different types of attachment to their environment, and these can be framed within the concept of 'insideness'. Rowles suggested three complementary dimensions of insideness: 'physical insideness', reflecting an intimate familiarity with the physical configuration of the environment; 'social insideness', arising from integration within the social fabric of the community; and 'autobiographical insideness', reflecting the way in which lifelong accumulation of experiences in a place can provide a sense of identity (Rowles, 1986).

Work in the field of environmental gerontology has been further explored in research around 'age-friendly' communities (WHO, 2007), and the related issue of developing supportive environments responsive to the aspirations and needs of older people (Buffel et al., 2012b). The theoretical questions here include: the meaning of home in the context of ageing (Rowles \& Chaudhury, 2005); processes of belonging and agency in person-environment interactions (Wahl \& Oswald, 2010); and the impact of neighbourhood characteristics on mobility and access in public spaces (Iwarsson et al., 2007). These and related questions have emerged as influential themes in gerontology, and have generated a wide range of practical applications for the design of residential and public spaces. At the same time, much of this work has remained insulated from wider debates in sociology and social geography, especially in relation to work around globalisation, migration and mobility. The next section of this paper examines the relevance of this field of work for understanding the lives of older people.

\section{Home and Migration: Transnational Belongings and Mobilities}

Since the early 1990s, globalisation theorists have emphasised that in a world characterised by mobility and migration, social life is increasingly shaped by the virtual and remote as opposed to the real and proximate. Identities are therefore seen as transient, mobile and diasporic (Savage et al., 2005). In his manifesto for a new 'sociology of mobilities', (Urry, 2000: 132) extended this dimension of globalisation, arguing that contemporary forms of dwelling and belonging 'almost always involve diverse forms of mobility'. Mobilities research focuses not only on the corporeal travel of people and the physical 
movement of objects, but also imaginative, virtual and communicative travel, enabling and coercing (some) people to live more 'mobile lives' (Elliott \& Urry, 2010; Sheller, 2011: 3).

Such themes have been further developed through work on 'mobile geographies of home', investigating the ways in which migrants dwell through travel, and vice versa (Ralph \& Staeheli, 2011: 519). Research in this field has challenged the way in which 'home' is imagined as territorially pre-defined and fixed, offering instead a conceptualisation of home as mobile, flexible and 'in-becoming' (Nowicka, 2007). This aspect has been emphasised in studies examining the meanings that migrants attach to home at different geographical scales, highlighting the deterritorialisation of belonging and attachments (Appadurai, 1996). At the same time, the desire to fix home with particular meanings by attaching it to an immediate locale is still apparent even for highly mobile transnational migrants (Butcher, 2010). Ralph and Staeheli (2011) make the point that there has been a tendency to overemphasise the shifting and mobile meanings of home, while underplaying migrants' struggles in, and attachments to, their current home. If we want to understand how migrants experience home, however, the key question remains: '... how (do) migrants build homes and identities through complex relationships that are plural, extensible, but nevertheless localised?' (Ralph \& Staeheli, 2011: 522, emphasis added). This point has been reinforced by Brickell and Datta (2011) who apply the concept of 'translocality' to enhance our understanding of the interconnections between mobility and locality, routes and roots, as well as transnational and local attachments (Clifford, 1997; Ehrkamp, 2005; Gustafson, 2009).

This last observation may be especially relevant to understanding the home-making practices of ageing labour migrants, a group who have been largely ignored in the context of research using the mobilities paradigm. Research has shown that first generation migrants often express emotional attachments to their place of origin as well as to their immediate neighbourhood (Phillipson et al., 2003; Gardner, 2006). Moreover, ageing labour migrants do not necessarily fall under the rubric of 'highly mobile transnational migrants' (Brickell \& Datta, 2011). They may for example experience constraints arising from declining health and/or limited financial resources, becoming increasingly dependent on the local environment for achieving a sense of home. The challenge, therefore, is not only to examine expressions of mobility, but at the same time explore the ways in which 'home' at the local level is experienced by diverse groups of ageing migrants.

Three research questions arising from the above will be addressed in this paper: first, how do ageing migrants understand and create 'home' in their current neighbourhood of residence? Second, what are the main elements identified by ageing migrants as impeding the development of a sense of 'home'? Third, what meanings do ageing migrants attach to their mobility and (potential) transnational relationships, and how do they evaluate the significance of such connections for the idea of 'home'?

\section{METHODS}

The data for the present research were derived from a qualitative study among first generation Turkish labour migrants living in two neighbouring districts in Brussels, home to a large Turkish immigrant community. The participants migrated to Brussels in the 1960s when the Belgian government was actively encouraging immigration to meet employment needs at a time of rapid urbanisation and economic expansion. Those who settled in Brussels originate in the main from Emirdağ, a rural town in central Turkey. Their settlement in Brussels coincided with changes in the socio-geographical make-up of the city, with large numbers of 'native' Brussels dwellers moving to the city's outskirts, leaving the deprived neighbourhoods to incoming migrants. The majority of the Turkish migrants in Brussels still live in these neighbourhoods which are characterised by high levels of deprivation (Manço \& Kanmaz, 2005).

Data were collected in 2010 among 34 migrants of Turkish backgrounds aged 60 and over. Interviews were undertaken by the author or by trained MSc students in the language of participants' choice (Turkish for all interviews). No interpreters were used; the author and interviewers were fluent in Turkish. Recruitment of participants ranged from the more formal to the fully informal: through relevant Turkish associations, voluntary and religious organisations as well as through informal meetings. Others were drawn through further 'snowballing' as well as through existing networks with social services. 
Participants chose the locations of the interview, and often permitted the interviewer in their home. Eighteen women and sixteen men participated in the study, with an age range of 60-78 years (although some exact birth dates were uncertain because of the absence of birth certificates). The interviewers were unable to recruit very elderly people (those 80 and over), partly because of the small number of first generation migrants from Turkish origin aged 80 and over or given the health conditions of many in this age group (see Table 1).

The study employed a semi-structured topic-list, including a range of issues such as older people's perceptions of home and neighbourhood; experiences of daily life; views about their social relationships; and the meaning of transnational ties. Interviews were audio-recorded, transcribed

Table 1. Socio-demographic characteristics of sample.

\begin{tabular}{|c|c|c|c|}
\hline & Women & Men & $\mathrm{N}$ \\
\hline Sex & 18 & 16 & 34 \\
\hline \multicolumn{4}{|l|}{ Age } \\
\hline $60-69$ & 14 & 12 & 26 \\
\hline $70-79$ & 4 & 4 & 8 \\
\hline \multicolumn{4}{|l|}{ Marital status } \\
\hline Married & 12 & 14 & 26 \\
\hline Widowed & 5 & 2 & 7 \\
\hline Divorced & 1 & - & 1 \\
\hline \multicolumn{4}{|l|}{ Educational level } \\
\hline $\begin{array}{l}\text { No educational } \\
\text { qualification }\end{array}$ & 9 & 4 & 13 \\
\hline Primary school & 7 & 7 & 14 \\
\hline $\begin{array}{l}\text { Secondary } \\
\text { education }\end{array}$ & 1 & 3 & 4 \\
\hline Higher education & 1 & 2 & 3 \\
\hline $\begin{array}{l}\text { Mean length of } \\
\text { residence in } \\
\text { neighbourhood }\end{array}$ & 20 years & 24 years & 22 years \\
\hline $\begin{array}{l}\text { Average number of } \\
\text { children }\end{array}$ & 4 & 3 & - \\
\hline \multicolumn{4}{|l|}{ Housing tenure } \\
\hline Homeowner & 10 & 11 & 21 \\
\hline $\begin{array}{l}\text { Private rental } \\
\text { housing }\end{array}$ & 6 & 4 & 10 \\
\hline $\begin{array}{l}\text { Social rental } \\
\text { housing }\end{array}$ & 2 & 1 & 3 \\
\hline \multicolumn{4}{|l|}{ Spoken language } \\
\hline Only Turkish & 12 & 5 & 17 \\
\hline Turkish/poor & 4 & 7 & 11 \\
\hline French or Dutch & & & \\
\hline Turkish/good & 2 & 4 & 6 \\
\hline French or Dutch & & & \\
\hline
\end{tabular}

Copyright (c) 2015 John Wiley \& Sons, Ltd. verbatim (in Turkish) and analysed using a combination of thematic and content analysis. The first step involved familiarising with the data by reading and re-reading the transcripts. The second step of the analysis entailed the coding of each interview on the basis of themes that were derived from the conceptual framework as well as directly from the interview data. In order to increase the credibility of the findings, the coding frames and strategies were subject to systematic review by the author and interviewers and refined through a process of consensus. Twenty-four different codes were identified, including 'migration history', 'returning home', 'neighbourhood likes', 'neighbourhood dislikes', 'neighbouring relationships', 'social relationships in Turkey', and 'return visits'.

All interviews were coded and analysed using ATLAS.ti. Once the interviews were coded, the author and interviewers identified how the themes were interrelated (Silverman, 2001), with the next step involving the clustering of codes into key themes or higher order headings (such as 'place attachment (local)', 'place attachment (Turkey)', 'environmental press', and 'transnational practices'). The author and interviewers then jointly re-read the interview data to refine and verify the overall themes to achieve validity in the findings. The analysis and coding took place on the original transcripts in Turkish. The quotes that were selected to include in the findings section of this article are the interviewers' or author's translation. In case of doubt or uncertainty, the translations were checked and refined by an official translation service. The research was conducted according to the Free University of Brussels' (VUB) code of ethics and good research practice.

\section{CREATING A SENSE OF HOME}

The first research question examined how migrants created a sense of home in their current neighbourhood. Four overall themes with regards to the development of home were identified: the idea of 'returning home'; 'social attachments to place'; 'physical attachments to place'; and 'engendered neighbourhood practices'. In relation to the first, the participants had migrated from economically depressed rural areas in Turkey to Brussels in the 1960s and 1970s, exchanging - in the case of the majority of men - a life of work on the land for one of manual labour in the construction industry, 
cleaning or railway sectors. Initially, the Belgian government emphasised the temporary nature of their employment: labour migrants, or socalled 'guestworkers', were assumed to return to their home country after their contracts expired (Abadan-Unat, 2011). However, this was the case for only a minority and the population of Turkish citizens continued to increase through migration based on family reunification, marriage and asylum. Nevertheless, the idea of 'temporariness' continued to be an important one for understanding the present struggles and problems experienced by participants. A 65-year-old man, who migrated to Brussels in his late 20s to work in construction, talked about this idea of temporariness:

'My plan was to go to Europe to work, save up money and then go back home... I never learned French because I always thought I would go back home. I've always spoken Turkish with everyone.'

As the above quotation illustrates, the idea of 'returning home' was a key feature in the participants' narratives about their relationship to both Brussels and to their place of origin. For two participants, both of whom had recently lost their partner, daily concerns arising from a combination of widowhood and poverty were some of the underlying reasons for wanting to return to Turkey. They also expressed feelings of homesickness for their country of origin:

'A part of my mind is in Turkey. There are many advantages of living in Brussels but it is nothing like Turkey. I always feel that something is missing' (67-year-old widow).

'I'm sick of this place. It is not [feasible to live here] and I can't make ends meet. Honestly... I am considering to move back to Turkey' (78-year-old widow).

Most participants, however, had adjusted to the idea of growing old in their second homeland. Their wish to 'return home' (see further Anwar, 1979; Phillipson et al., 2003) had become increasingly unlikely because of a combination of emotional and practical reasons. This was reflected in the following comments:
'I can't move away from my neighbourhood. My roots are here now because my children live here... Hospitals are good, and we have insurance and social rights. Brussels has a lot of advantages' (74-year-old woman).

'I would definitely prefer to grow old in my country [Turkey]... But I don't think I would be able to manage that. My children live here. I go back to Turkey for 3 to 4 months a year, but then I miss my grandchildren too much. I also don't have as many friends in Turkey as I have here. People are different there... Sometimes I feel like a stranger in my own country' (63-year-old man).

Alongside family, health-care and social security related factors, opportunities to maintain transnational ties were identified as important reasons for staying permanently in Brussels (see also, White, 1997). Some participants also referred to the transformations that had occurred in their homeland, which made it more difficult for them to identify with their place of origin. The length of time participants had lived in their neighbourhood in Brussels (an average of 22 years) was an additional contributory factor to their preference to 'age in place' (Rowles, 1986).

\section{Social Attachments to Place}

The participants interviewed for the study also commented on how they had worked to transform their current physical environment into a meaningful place, one where they feel at home and to which they felt attached to varying degrees. Such a sense of home was itself both created and reinforced through the proximity of members of their own cultural community, creating opportunities for common social bonds. This was illustrated in comments such as:

'I wouldn't want to [move away from here] because I don't want to live far away from all the Turkish people. When I go out here I always meet family and friends on the street; and that gives me a sense of relief. I am already in a foreign country... if I would live somewhere far away from the Turkish community, it would feel as if I'm moving to a foreign country for the second time' (69-year-old woman).

Popul. Space Place (2015) DOI: $10.1002 / p s p$ 
'The best thing about living here is that there is a large Turkish community. I don't feel like a stranger here, we are all the same' (64-yearold man).

The interviews suggest that the social network of most of the participants was strongly oriented towards the (extended) family. The majority had their children and grandchildren living in fairly close proximity to their homes and had a regular and intense level of family contact. At the same time, the term 'akrabalar' - meaning 'relatives' or 'kin' was often used in a broad sense, not only referring to relatives, but to everyone who migrated from the same village or region in Turkey, reflecting supportive, reciprocical bonds across members of the community:

'We treat the people from our village [the village they migrated from in Turkey] as our relatives' (63-year-old woman).

‘People from Emirdag are like a close-knit family. Relatives, friends and neighbours around

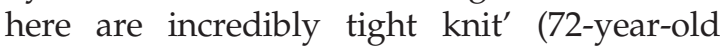
woman).

Our analysis of the participants' social relationships further provided support for Warburton and McLaughlin's (2007) point that older people from diverse cultural backgrounds contribute to social capital in a variety of ways. The men in this study especially talked about their engagement in religious activities organised by the mosque, while women's narratives about social support appeared to be centred on relatives, sick or vulnerable people in the community, and the looking after, or being looked after, by neighbours. A 71-year-old man, for example, said:

'Because I'm active in the mosque association, I know many people. I have connections with almost everyone around here. We organise language courses, trips, and activities for young people. I meet my friends in the mosque, we go for tea after or we meet each other in our homes.'

Typical comments amongst female participants included:
'I am very happy with my neighbours. They helped me a lot when I was having a difficult time after my husband died. May God reward them' (74-year-old woman).

'They [neighbours] are very important to us... Even in the smallest of matters one neighbour can help another [...] "Komsu komsuya muhtaçtır" [loosely translated as: It's better to have a good neighbour than a distant friend]' (64-year-old woman).

As reflected in these quotes about the role of neighbours, the interviews revealed a range of Turkish expressions about the value of 'neighbourliness', both among women as well as men. Some participants made this point by using the Turkish proverb 'find your neighbour, choose your house', suggesting that trustful and supportive neighbours are the most important criterion for determining the choice of a home. Other expressions included: 'neighbours are like family in our culture' and 'neighbours have indisputable rights to each other'. Typical examples of such 'rights' were found in the reciprocal support, both emotional as well as practical, provided to one another, in terms of 'helping each other financially' when needed (71-year-old man) and 'visiting neighbours when they have a problem or when they are ill' (74-year-old woman).

The above findings point to the importance of what Rowles (1986) termed 'social insideness' in developing a sense of home, both in terms of kinship relations and friendships as well as neighbour relationships, especially with those from the same cultural community. Sharing similar migration histories, speaking the same language, sharing Islamic values, and living in the same neighbourhood all seem to facilitate this social attachment to place. As previously suggested by Becker (2003), the wealth and complexity of the participants' common social bonds appear key to understanding what keeps those older people 'rooted in place'.

\section{Physical Attachments to Place: The Proximity of Ethnic Amenities}

A further dimension to the creation of home was the importance of proximity to ethnic amenities and services. Since the 1980s, with family 
reunification largely complete, the Turkish community had become more visible with the building of mosques, the establishment of ethnic and religious associations, the celebration of religious holidays, and the opening of ethnic businesses. This community is often referred to as 'Little Turkey' as it has formed a self-sufficient enclave, where Turkish restaurants, halal butchers, teahouses, groceries, jewellers, and bookshops serve their predominantly Turkish clientele. Access to such 'third places' where 'imagined communities' can be sustained (Oldenburg, 1989) was considered to be of major importance by many:

'Everything we need is close by: the mosque; the hospital; the pharmacy; Turkish markets; halal butchers... My children live nearby and I have Turkish neighbours. For me, a good neighbourhood is one with good neighbours and good streets where you feel safe... What else do we need? (64-year-old man)

‘We found peace here... I got to know my nextdoor neighbours well... people are warm, there is a good atmosphere and there are plenty of Turkish markets and shops... I can walk to the grocery round the corner to get fresh vegetables... And we also have a mosque nearby' (63-year-old woman).

'I love this neighbourhood. It feels a bit like Turkey. It's like "back home". We have a mosque; there are many Turkish shops where we can buy cheap products; there are Turkish restaurants, and we know all the owners' (63-year-old man).

The findings presented here provide support for what Rowles (1986) termed 'physical insideness', reflecting an intimate familiarity with the physical configuration of the neighbourhood, created and re-created through participants' engagement in transnational home-making practices. 'Home' in this context becomes a place through which migrants establish a connection with the place they left behind. Mosques, satellite dishes, teahouses and ethnic businesses act as material links here between two worlds within 'transnational social space' (Ehrkamp, 2005).
They not only link the participants to the Turkish community in their neighbourhood, but also enhance a sense of 'imaginative mobility' (Elliott \& Urry, 2010), allowing them to 'be' in Turkey in their minds without physically being there.

\section{Engendered Neighbourhood Practices}

A final theme that emerged from the data suggested that there was a clear gender dimension to the creation of home, which was especially evident through the neighbourhood practices of the participants. Ethnographic observations demonstrated that Turkish older men tend to have more informal gatherings with friends outdoors than women, for example in the mosque or teahouses. During the interviews, there was a tendency among women as well as men to refer to these places as 'male spaces'. Teahouses in the neighbourhood were exclusively geared towards the need of Turkish male residents, offering opportunities to play games, gamble, watch Turkish football and socialise with other older men, who in most cases, originated from the same village of origin. A 67-year-old man, for example, explained his daily routine as follows:

'I usually wake up quite early, I have breakfast, and then I go to see [his friends] in the Turkish teahouse around the corner... What do we do? We drink tea, just chat about general things... play tavla [backgammon]... And on Friday I go to the mosque. They [his friends] go as well.'

In contrast, the women in this study visited the mosque less frequently (in most cases only on important religious days), and often reported a lack of 'female spaces' or family-friendly places in the neighbourhood. One 66-year-old woman, for example, argued:

'There are no activities around here, especially for the women. What we need here is a social space where we can take our grandchildren and have a chat with other women: A place for the women to get together.'

Islamic prescriptions, outlining that men and women should keep sufficient physical distance 
and should not meet in private, may further support 'male territoriality' in this neighbourhood, because women should not enter a space in which men are already present (Peleman, 2003: 159). The capacity to be 'mobile' in public space, both physically and socially, thus has a clear gender dimension. This was illustrated in our study through a comment made by an older Turkish woman in Brussels who avoided a particular place as she was worried that men would spread gossip about her, which could damage her reputation in the community:

'I only go shopping in the shop at the corner; I don't go to [the supermarket] because I have to pass that square then where all the men are' (63-year-old woman).

However, there was also evidence that older women succeeded in appropriating certain places (Peleman, 2003). This was especially the case in private spaces; in their home or in the homes of family of friends where they had informal meetings amongst women, but also in some semi-public spaces such as associations and community centres, where women came together to attend language courses or programmes against illiteracy, and to do voluntary work, such as cooking for friends who run local businesses.

\section{CONSTRAINTS ON THE CREATION OF HOME}

The second research question concerns issues which might impede the development of a sense of 'home'. Two interacting themes were identified: first, the deprived urban neighbourhoods in which participants live; second, the different forms of disadvantage that have accumulated over their life course. In terms of the latter, and in line with previous research on older labour migrants (Warnes, 2004), participants often reported a lifetime of disadvantage, including financial insecurity, limited education, poor working and housing conditions, barriers related to language, and discrimination on the basis of race and religion. The accumulation of disadvantages over the lifecourse presented particular challenges for maintaining a sense of home and wellbeing in old age. Early experiences such as poor socio-economic and working conditions for example had an impact in later life, especially on physical and mental health. A 63year-old man commented:

'My health isn't good. It started with backaches when I was still working in construction; we were building the subways in Brussels... A friend of mine died in a work-related accident; others gained long-lasting injuries... I think I became ill because of working too hard. I'm having breathing problems and headaches, and my legs are tired. The older I get the worse it gets.'

For participants such as the above with health problems, the experience of 'ageing in place' raised various problems, especially when linked to issues of poverty and poor housing conditions. Several interviewees expressed their discontent with the housing conditions and neglect of the area, which presented particular challenges to maintaining a sense of home. The underlying reason for staying in their present home was financial with the relatively low rents discouraging them from moving:

'Earning a living here is difficult and everything is more expensive. Turkey has much more advantages. I'm not happy with where I live at all. Brussels is not safe anymore. It has gone downhill and it has affected our children. We don't let them go out at nights' (77-year-old man).

'We spend over half of our income on rent. Turkish people around here have always struggled financially. We can't afford to live somewhere else. We are forced to live in this neighbourhood out of economic necessity' (71-year-old woman).

The findings also highlighted barriers linked to the urban deprivation in the area, including the physical deterioration of infrastructure and the lack of outdoor seating and pedestrian safety, which prevented participants from moving between their homes, neighbourhoods, and public spaces. A number of participants commented on the poor quality of their environment: 
'The roads are dirty and full of cigarette butts and cans. They throw everything on the floor. Despite cleaning our front door, they always make it filthy it again... And pubs are open all night round here, until the morning hours. They make a lot of noise. But where can we make a complaint? The municipality never does anything. There is no order and hygiene anymore in this neighbourhood' (64-year-old woman).

'The pavements and streets are very narrow and dangerous. People get hit by cars when they try to cross the road' (71-year-old man).

'The biggest problem in this area is the busy traffic and the fact that there are too many cars... There are no benches and there is hardly any green space around here' (66-year-old woman).

These, among other interviews, provided insights into some of the structural barriers which may cause 'environmental press' for older people (Lawton \& Nahemow, 1973). Such pressures may present particular challenges to maintaining a sense of home, especially when their person's capabilities to deal with these are restricted.

\section{TRANSNATIONAL RELATIONSHIPS AND MOBILITIES}

The final research question concerns the meaning of mobility and transnational relationships for the research participants, and how they evaluate the significance of such connections to the idea of 'home'. As discussed earlier, ageing migrants may be attached to multiple places as they often maintain linkages both to their current neighbourhood and their place of origin (Gardner, 2006). The following excerpts illustrate how several ageing migrants felt emotionally attached to both their present place of residence and their place of origin, reflecting the ambivalent nature of their sense of home and place:

'I feel like this [neighbourhood in Brussels] is my home now, but I also miss the mountains and scenery in my home in Turkey' (71-yearold woman).

'I feel very much attached to my neighbourhood. Whenever I go to Turkey I miss my friends and children [who live in Belgium]. But when I'm here, I miss my family in Turkey' (64-year-old man).
While most felt reasonably comfortable with ambiguous boundaries and had achieved a certain degree of feeling at home in both places, the ways in which participants negotiated their multiple sense of home also revealed expressions of 'placelessness' among some. According to Phillips (2011: 81), placelessness may be 'a result of exclusion or may itself lead to exclusion being made unwelcome or not having the resources to engage in the spatial environment'. Such a sense of exclusion was evident for example in the following comment made by a man: 'In Turkey we are viewed as Europeans, and here we are viewed as foreigners', this reflecting his feelings of not-fullybelonging to either place (see also Bolzman, in this issue). Further in the interview, he explained that 'European Turks' are often portrayed as 'gâvur' by Turks in Turkey, a derogatory term denoting infidelity or immorality:

'Our village has also changed. The people... I don't know why, but it feels less welcoming. They are less sincere perhaps. When we arrive in the village, they point at us: "look, the gâvurlar"' (67-year-old man).

Despite this sense of alienation, like most participants, this man continued to travel back and forth between Turkey and Belgium, while at the same time forming attachments to both locations. The majority travelled at least once a year to their home country, either by car with their children or thanks to cheap flights, with the summer months being the most popular time to visit the homeland. This, for example, was a typical comment:

'I go back to my country once a year. My aunt, cousins, my father's cousins; they all live there. I visit them every year and we phone regularly. I miss my hometown... but we stay in touch' (67-year-old woman).

Keeping in touch with relatives through telephoning or visiting them, caring for a family member who was ill, getting children married 'to a Turk from Turkey' and attending weddings and funerals were identified as the main reasons for visiting the homeland. Some of them also owned a house in their country of origin. Many participants attached great importance to such 'back and forth' travels, and those who were restricted in their mobility to travel back to Turkey 
were very conscious of this deficiency, which they tried to compensate for by telephoning their friends and family in Turkey:

'It's difficult to be far away from each other. But I talk with my mother on the phone as if we are sitting right next to each other. That is how we reduce the distance between us' (71-year-old woman).

What was evident from this and other interviews is that the support between ageing migrants and their parents was maintained across considerable geographical distance (see, also, Baldassar, 2007). Communicative and imaginative forms of mobility by phone or computer (Urry, 2000) may become increasingly important among ageing migrants in this respect, especially as they allow people to 'be' in a distant place without physically being there, as reflected in the comment above.

\section{DISCUSSION}

This paper has explored the ways in which first generation Turkish labour migrants who are ageing in a deprived neighbourhood in Brussels experience and create 'home', both as a location and a set of mobile relationships that contribute to feelings of belonging and identity (Ralph \& Staeheli, 2011). The study showed that the idea of 'returning home' for their retirement was a key feature of this generation's relationship to both Brussels and their place of origin, highlighting their experiences of entanglement between living in Brussels and desiring to spend their old-age in Turkey. Despite a persistent longing to return to the homeland, however, participants had, to a greater or lesser extent, adapted to the idea of 'ageing in place', or growing old in their current neighbourhood in Brussels. A range of elements are identified by the participants as important reasons for staying permanently in Brussels: health-care and social security support; emotional and social distance from the homeland; opportunities to maintain transnational ties (either through back and forth travels or regular telephone calls); and the length of residence participants had lived in their neighbourhood in Brussels. The most important reason, however, appeared to be linked to participants having family or strong community ties in the locality, these representing a key element for understanding 'what keeps these elders rooted in place' (Becker, 2003: 145). Indeed, the participants' narratives about their (re)creation of a 'sense of home' are strongly linked to the strategies adopted to achieve 'social insideness' (Rowles, 1986), arising from everyday social exchanges and the creation and maintenance of social roles and networks within their neighbourhood and families.

Following the above, the study supports previous research highlighting the advantages of mutual social support and stronger sense of belongingness offered by living in close proximity to others with the same ethnic background (see Becares \& Nazroo, 2013). The findings also suggest that notions of home and place may have different meanings for female and male ageing migrants, especially as the sexes in Islamic communities occupy different and segregated spaces and men and women are allotted different rights and different cultural expectations (Peleman, 2003). Public (the mosque, tea houses) and private (the private home) spaces are often differentiated by the participants in relation to conceptions of 'male' and 'female' spaces, and women are naturally seen as the outsiders of these male 'public' spaces. This was also linked to some female participants' comments about the lack of 'female' spaces in the neighbourhood, reflecting a need for local meeting places where women can get together outside the private home.

Ideas of home in this research have revealed multiple place attachments that are reproduced within the local environment as well as through mobility (Ralph \& Staeheli, 2011), whether physical (back and forth travels), virtual (telephone contact with family and friends in Turkey), or imaginative (desires to return home). At the level of the neighbourhood, this is especially evident in the way 'home' is experienced and created as a site of connection within and across communities, reflecting a transnational sense of belonging. By engaging in their communities, establishing communal and religious places such as mosques, and making use of ethnic amenities, ageing migrants play a role in reconstructing and transforming their neighbourhood into a transnational social place. Many participants connect their sense of local place attachment to such transnational practices, suggesting that these enable 
them to create a sense of home, rather than preventing it (Ehrkamp, 2005). According to Clifford (1997: 155), the process of recreating places of belonging (based on faith, culture, language or shared interests) in the neighbourhood plays an important role in mediating 'the experiences of separation and entanglement, of living here and remembering/desiring another place'. This research suggests that this may be of particular importance for ageing migrants who become increasingly dependent on the local environment for achieving a sense of home, for example because of declining health, restricted mobility and/or limited financial resources. By focusing not only on the physical mobility of ageing migrants (e.g. back and forth travels) but also the mobility of objects and social practices (e.g. Turkish tea, food, and mosques) and virtual and imaginary forms of mobility (Urry, 2000), the mobilities paradigm provides a powerful framework here for understanding the variety of ways in which ageing migrants may compensate for the loss of connections with the homeland based on physical proximity.

The study further shows that a focus on place not only identifies the way in which ageing migrants create home, but also the challenges in maintaining a sense of home. Two in particular are identified: first, the deprived urban neighbourhoods in which participants live and second, the different forms of disadvantage that have accumulated over their lifecourse, presenting particular challenges in old age. The experience of place, in this context, emerges as a central site of daily struggle, arising from financial hardships, poor housing conditions, language barriers and experiences of exclusion (see, also, Becker, 2003). The participants in this study highlight a range of structural and environmental barriers linked to urban deprivation, such as the physical deterioration of infrastructure and the lack of outdoor seating and pedestrian safety, these restricting their daily mobility and social life. Evidence suggests that older adults with limited personal resources, and especially those who had a lifetime of disadvantage and deprivation, are particularly prone to such 'environmental press', and this can undermine people's sense of home and wellbeing (Lawton \& Nahemow, 1973).

Three limitations of the study should be highlighted. First, the research only includes participants who migrated from a particular region in central Turkey who live in one area of Brussels. Further research could include comparative analysis of transnational belongings among more heterogeneous groups of ageing migrants in multiple sites to examine the significance of context in the creation of home (Walsh, 2014). A second limitation is that the researchers were unable to recruit the oldest old (80 and over) and the most vulnerable, homebound older people. Given the rapidly increasing number of ageing migrants who are 'ageing in place' in European cities, the oldest members of the migrant population deserve far more research attention than is currently the case. Finally, further research could address questions of return in more detail, not only among ageing migrants who travel backand-forth, but also among those who decide to return to Turkey in old age. New 'mobile methods' (Sheller, 2011) could capture some of the dynamic processes and issues around (im)mobilities here, building on an approach that moves beyond both geographical fixity and disciplinary boundaries.

Despite the above, the study represents a first attempt to combine insights from environmental gerontology and transnational migration studies to advance our knowledge about the meanings ageing migrants attach to the idea of 'home'. The argument developed is that both fields would benefit from working more closely together. Work on transnationalism for example has been highly influential in engaging with migrants' attachments to distant and remote homes (Ralph \& Staeheli, 2011). However, such discussions have been largely detached from the various problems facing their local urban environments, notwithstanding the fact that many migrant groups reside in inner-city neighbourhoods experiencing relatively high levels of deprivation. Environmental perspectives on ageing could offer a way forward in this respect, especially as they relate to the experiences of urban life and neighbourhood exclusion in the creation of home in later life. On the other hand, environmental gerontology would benefit from an integration of a lifecourse perspective on people's migration and mobility trajectories. A dynamic perspective on 'ageing in place' is especially needed to understand how connections to 'multiple places' are integrated in experiences of home among transnational migrants (Johansson et al., 2013). This will be especially 
important given the complexity of biographical journeys among ageing migrants. Spaces of belonging are often developed at different geographical scales - the local, national or transnational communities in which people think of themselves as 'feeling at home' (Morley, 2001). This points to the need for re-thinking the nature of social policy in a global world, where people 'revisit' home physically, virtually and psychologically (Buffel \& Phillipson, 2011). Identities, place attachments and families no longer respect national borders. In this respect, first generation migrants are pioneers of a new social and economic order, raising major issues for research and policy regarding the role of place in ageing and the experience of ageing in place.

\section{ACKNOWLEDGEMENTS}

The author would like to thank Sema Sönmez and Serpil Saglam for their dedication to the fieldwork; the Belgian Ageing Studies research group; members of the Population and Ageing and Urbanisation (INPAU) network; and everyone who participated in the research. A special thank you to Chris Phillipson, James Nazroo, Bethan Harries and the editors whose comments and suggestions were particularly helpful in writing this paper.

\section{REFERENCES}

Abadan-Unat N. 2011. Turks in Europe: From Guest Worker to Transnational Citizen. Berghahn Books: New York.

Anwar M. 1979. The Myth of Return. Heineman: London.

Appadurai A. 1996. Modernity Al Large: Cultural Dimensions of Globalization. University of Minnesota Press: London.

Baldassar L. 2007. Transnational Families and Aged Care: The Mobility of Care and the Migrancy of Ageing. Journal of Ethnic and Migration Studies 33: 275-297.

Becares L, Nazroo J. 2013. Social Capital, Ethnic Density and Mental Health Among Ethnic Minority People in England: A Mixed-Methods Study. Ethnicity $\mathcal{E}$ Health 18: 544-562.

Becker G. 2003. Meanings of Place and Displacement in Three Groups of Older Immigrants. Journal of Aging Studies 17: 129-149.
Brickell K, Datta A. 2011. Translocal Geographies: Spaces, Places, Connections. Ashgate Publishing, Ltd: Surrey.

Buffel T, Phillipson C. 2011. Experiences of Place Among Older Migrants Living in Inner-City Neighbourhoods in Belgium and England. Diversité Urbaine 11: 13-37.

Buffel T, Verté D, De Donder L, De Witte N, Dury S, Vanwing T, Bolsenbroek A. 2012a. Theorising the Relationship Between Older People and Their Immediate Social Living Environment. International Journal of Lifelong Education 31: 13-32.

Buffel T, Phillipson C, Scharf T. 2012b. Ageing in Urban Environments: Developing 'Age-friendly' Cities. Critical Social Policy 32: 597-617.

Butcher M. 2010. From 'Fish Out of Water' to 'Fitting In': The Challenge of Re-Placing Home in a Mobile World. Population, Space and Place 16: 23-36.

Carp FM. 1966. A Future for the Aged. University of Texas Press: Austin.

Clifford J. 1997. Routes. Travel and Translation in the Late Twentieth Century. Harvard University Press: Cambridge.

Ehrkamp P. 2005. Placing Identities: Transnational Practices and Local Attachments of Turkish Immigrants in Germany. Journal of Ethnic and Migration Studies 31: 345-364.

Elliott A, Urry J. 2010. Mobile Lives. Routledge: London. Gardner K. 2006. Narrative, Age and Migration: Life History and the Life Course Amongst Bengali Elders in London. Berg: Oxford.

Gustafson P. 2009. Mobility and Territorial Belonging. Environment and Behavior 41: 490-508.

Iwarsson S, Wahl H-W, Nygren C, Oswald F, Sixsmith A, Sixsmith J, Széman Z, Tomsone S. 2007. Importance of the Home Environment for Healthy Aging: Conceptual and Methodological Background of the European ENABLE-AGE Project. The Gerontologist 47: 78-84.

Johansson K, Rudman DL, Mondaca M, Park M, Luborsky M, Josephsson S, Asaba E. 2013. Moving Beyond 'Aging in Place' to Understand Migration and Aging: Place Making and the Centrality of Occupation. Journal of Occupational Science 20: 108-119.

Lawton MP. 1982. Competence, environmental press, and the adaptation of older people. In Aging and the Environment: Theoretical Approaches, Lawton MP, Windley PG, Byerts TO (eds). Springer: New York; 33-59.

Lawton MP, Nahemow L. 1973. Ecology of the aging process. In Psychology of Adult Development and Aging, Eisdorfer C, Lawton MP (eds). American Psychological Association: Washington DC; 619-24.

Manço U, Kanmaz M. 2005. From conflict to cooperation between muslims and local authorities in a Brussels borough: Schaerbeek. Journal of Ethnic and Migration Studies 31: 1105-1123. 
Morley D. 2001. Belongings: Place, Space and Identity in a Mediated World. University of Copenhagen: Copenhagen.

Nowicka M. 2007. Mobile Locations: Construction of Home in a Group of Mobile Transnational Professionals. Global Networks 7: 69-86.

Oldenburg J. 1989. The Great Good Place. Paragon Books: New York

Peace S, Kellaher L, Holland C. 2005. Environment and Identity in Later Life. Open University Press: Maidenhead.

Peleman K. 2003. Power and Territoriality: A Study of Moroccan Women in Antwerp. Tijdschrift Voor Economische En Sociale Geografie 94: 151-163.

Phillips J. 2011. How do Unfamiliar Environments Convey Meaning to Older People? Urban Dimensions of Placelessness. International Journal of Ageing and Later Life 6: 73-102.

Phillipson C. 2007. The 'Elected' and the 'Excluded': Sociological Perspectives on the Experience of Place and Community in Old Age. Ageing and Society 27: 321-342.

Phillipson C, Ahmed N, Latimer J. 2003. Women in Transition. A Study of the Experiences of Bangladeshi Women Living in Tower Hamlets. Policy Press: Bristol.

Ralph D, Staeheli A. 2011. Home and Migration: Mobilities, Belongings and Identities. Geography Compass 5: 517-530.

Rowles GD. 1986. The Elderly of Appalachia. Appalachian Center, University of Kentucky.

Rowles GD, Chaudhury H. 2005. Home and Identity in Late Life: International Perspectives. Springer: New York.
Savage M, Bagnall G, Longhurst BJ. 2005. Globalization and Belonging. SAGE: London.

Sheller M. 2011. Mobility. Sociopedia. Available at: http:/ /mcenterdrexel.wordpress.com/2011/07/15/ sociopedia-mobility/

Silverman D. 2001. Interpreting Qualitative Data: Methods for Analysing Talk, Text and Interaction. Thousand Oaks: New Delhi.

Torres S. 2013. Transnationalism and the study of aging and old age. In Aging in European Societies, Phellas C. (ed.). Springer: New York.

Urry J. 2000. Sociology Beyond Societies: Mobilities for the Twenty-first Century. Routledge: London.

Wahl H-W, Oswald F. 2010. Environmental perspectives on ageing. In The SAGE Handbook of Social Gerontology, Dannefer D, Phillipson C. (eds). SAGE Publications: London; 111-124.

Walsh K. 2014. Placing Transnational Migrants Through Comparative Research: British Migrant Belonging in Five GCC Cities. Population, Space and Place 20: 1-17.

Warburton J, McLaughlin D. 2007. Passing on our Culture: How Older Australians from Diverse Cultural Backgrounds Contribute to Civil Society. Journal of Cross-Cultural Gerontology 22: 47-60.

Warnes AM. 2004. Older Migrants in Europe: Essays, Projects and Sources. Sheffield Institute for Studies on Ageing: Sheffield.

White JB. 1997. Turks in the New Germany. American Anthropologist 99: 754-769.

World Health Organization. 2007. Global Age-friendly Cities: A Guide. WHO: Geneva. 